Murray State University

From the SelectedWorks of Cris Ferguson

2017

\title{
Open Educational Resources and Institutional Repositories
}

Christine L Ferguson, Murray State University 
Balance Point

Open Educational Resources and Institutional Repositories

Cris Ferguson, Column Editor

Director of Technical Services, Waterfield Library, Murray State University, Murray, KY 42071;

phone: 270-809-5607; email: cferguson13@murraystate.edu

Keywords

Creative Commons license; funding; institutional repositories; OER; IR; open educational resources; staffing

\begin{abstract}
This installment of the Balance Point column delves into the ways in which libraries create and store open educational resources (OER) in institutional repositories (IR), addressing issues such as preservation and versioning of OER content, copyright and licensing, funding, and staffing. Drawing on interviews and the literature, programs at institutions such as the University of Minnesota, the University of Kansas, and Grand Valley State University are highlighted.
\end{abstract}

\title{
Introduction
}

In volume 42, issue 3, of Serials Review, this column discussed how libraries are providing access to textbook materials, including print reserves, ebooks, and open educational resources (OER). Highlighted in that column was the North Carolina State University (NCSU) Libraries' 
Alt-Textbook program, through which the NCSU Libraries support the creation of open educational resources both financially and programmatically. The NCSU Libraries are far from alone in this effort. Many other academic libraries are also venturing into the production of OER to provide access to flexible course materials at little to no cost to students. Continuing in the vein of the "Textbooks in Academic Libraries" column, this installment of Balance Point further details the ways in which libraries create and store open educational resources in their institutional repositories, addressing issues such as copyright and licensing, updating and versioning of OER content, funding, and staffing issues.

As institutional support for the creation of open educational resources is relatively new, there is no single blueprint or roadmap for establishing a successful OER program at an academic library. In a recent article in College \& Undergraduate Libraries, Goodsett, Loomis, and Miles (2016) identify several key elements that must be in place before beginning an open access or OER publishing program: "libraries must select a publishing platform, establish a publishing mission, outline services, create branding, and provide a printing service.” However, not all institutions consider each of those elements to be critical to their services. Library services in support of OER cover a wide range of scholarly activities, from copyright and licensing assistance to content creation and storage.

\section{Library support of OER}

In many cases, open educational resources are often textbooks, but the term OER could also encompass videos, journals, audio recordings, visual materials, and other types of course content. 
Institutions have taken a variety of approaches when selecting OER content to produce and publish; some have focused on broad, general use content, whereas others have selected content areas unique to their institution. For example, Rice University's OpenStax initiative has focused on creating open texts for high-enrollment lecture hall courses, whereas Oregon State University has opted to highlight those subject areas where the university has an existing reputation, such as horticulture, animal sciences, and geosciences (Chadwell \& Fisher, 2016). Early in their OER initiative, the University of Minnesota (UMN) Libraries made the decision to republish content from Flat World Knowledge, a textbook publisher that originally offered its textbooks for free under an open content model. They also published new, original open textbooks, says Shane Nackerud, technology lead of Library Initiatives at UMN Libraries (S. Nackerud, personal communication, October 6, 2016).

As universities establish programs to produce and promote OER content, libraries are playing an active role in support of these OER initiatives, sometimes spearheading the efforts. However, the ways in which libraries offer support for OER creation and adoption vary widely. Some libraries assist in identifying and producing content, while others help with copyright permissions, licensing, and metadata creation.

The Grand Valley State University (GVSU) Libraries first began hosting OER in 2011 and established a campuswide interest group in late 2014. According to Sarah Beaubien, head of collections, the GVSU Libraries offer copyright consultation with authors, upload content into the repository, and enter author-supplied metadata. The Libraries also provide the platform, 
bepress' Digital Commons, on which the content is hosted (S. Beaubien, personal communication, October 10, 2016). Beaubien added that the GVSU Libraries partner with other units across campus if faculty require services beyond what the library is able to provide.

Created in 2012, the UMN Libraries' eLearning Support initiative strives to integrate library resources and services into an overall campus focus on eLearning at the University of Minnesota. As part of the eLearning Support initiative, the UMN Libraries began investigating open textbooks and OER, including campus advocacy for those resources and how the library could help faculty and instructors publish OER and open textbooks. The eLearning Support initiative and the UMN Libraries' Publishing Services initiative jointly publish open textbooks. "We do provide some copyright assistance, ISBN creation, indexing, and the creation of the books themselves. We do not provide copy-editing or graphic design,” explains Nackerud (S. Nackerud, personal communication, October 6, 2016).

The OER program at the University of Kansas (KU) Libraries began in earnest in the summer of 2015, when the KU Libraries joined the Open Textbook Network. Through its OER grant program, the KU Libraries offer consultations, funding, assistance with copyright and licensing, deposit of content in the institutional repository with metadata, and possibly in the future some marketing of the material. Josh Bolick, scholarly communications librarian at the KU Libraries, indicates that outside of the grant program, they are available to assist instructors in identifying OER for their classes, as well as clarifying what kinds of uses are permitted under a given Creative Commons (CC) license (J. Bolick, personal communication, October 10, 2016). 


\section{Use of institutional repositories}

A number of large repositories house and provide access to OER content. Examples include the University of Minnesota's Open Textbook Library; the California Open Online Network for Education (Cool4Ed), supported in part by the California State University System; and The Orange Grove, Florida’s Open Educational Resource Repository. All three of these repositories house OER from a large number of educational institutions from across the United States.

Libraries and institutions producing open educational resources are able to deposit the content into these repositories for access by their own faculty, as well as members of the larger academic community.

However, a growing number of universities are turning to their local institutional repositories (IR) as a primary access point for the open textbooks and OER content produced by their faculty, staff, and students. To cite a few examples, both the Michael Schwartz Library at Cleveland State University (CSU) and GVSU Libraries use the Digital Commons (DC) platform from bepress to provide access to the OER produced at their institutions (Goodsett et al., 2016; S. Beaubien, personal communication, October 10, 2016). California State University San Marcos' (CSUSM) ScholarWorks program utilizes DSpace Repository, an open source platform, support for which is provided by the California State University Chancellor's Office (Mitchell \& Chu, 2014). The UMN Libraries make use of two repository-type platforms: Pressbooks for their OER content and bepress for mainly journal content. "Most of our OER (primarily open textbooks right now) are hosted on our Pressbooks install. I can see us hosting more on our bepress install, 
especially math and PDF based content, in the future," says Nackerud (S. Nackerud, personal communication, October 20, 2016).

The KU Libraries also turned to their repository, dubbed KU ScholarWorks (KUSW), to house their OER, in part due to the existing infrastructure it provides. Josh Bolick explains:

The repository has been active at KU for quite a while, with the primary target content being published journal articles. We've realized what so many other members of the open and IR communities realized, which is that IR can be used more broadly than journal articles and conference proceedings. One of those potential uses is OER. So rather than building infrastructure and deposit workflows we're able to focus on OER programmatically and leverage the IR as a means for providing access and preservation. (S. Bolick, personal communication, October 10, 2016)

As Bolick indicates, one of the compelling reasons for using an institutional repository to house and store OER content revolves around the issue of preservation.

$[\mathrm{P}]$ reservation of open educational resources is a significant challenge due to the short lifespan of repositories in which they are typically housed... Preservation is an area for libraries to take a look at where they can help, but right now the burden is on creators of OER to create backups of their work and on users of OER to be sure thatthey have copies of materials they may want to use in the future. (Hess, Nann, \& Riddle, 2016) 
By ingesting OER files and metadata in an institutional repository, the library helps faculty members and students create backups of their content and manage the long-term preservation of OER resources.

Going hand in hand with the issue of preservation is the issue of versioning.

For instructors ... a significant advantage to the OER is the ability to pick and choose the pieces of each resource they want to use. Their modular nature allows instructors to use only relevant components and customize materials for more specific topics and audiences. (Hess et al., 2016)

This modular nature can lead to a proliferation of different versions. Each time a text is used and customized, it effectively produces a new edition or version to be archived. Institutions have taken a variety of approaches toward handling the issue of versioning.

The GVSU Libraries currently have 10 OER in their repository, ScholarWorks@GVSU. A few of those OER are previous or more current editions of the same work. Sarah Beaubien explains, "Because we use an institutional repository as our hosting platform, we don't like to remove previous editions. This is why we treat updates as subsequent editions" (S. Beaubien, personal communication, October 10, 2016). At the University of Minnesota Libraries, which currently has 23 OER available, the issue of versioning has not been completely addressed. Says Nackerud, 
The content is the job of the faculty. Already faculty have been very good at keeping content up to date. However, it does bring up the sticky issue of versioning. When do we need to create new editions (and new ISBNs)? That is not something we have completely figured out yet. (J. Nackerud, personal communication, October 10, 2016)

Key to the success of open educational resources, particularly those in an institutional repository, is their visibility and availability. In a 2015 survey, Texas A\&M University (TAMU) Libraries queried TAMU faculty regarding their perceptions of open access trends and resources, including open textbooks. "The results showed that $48 \%$ of respondents were not aware of open textbooks, while 13\% plan to adopt open textbooks in their teaching" (Yang \& Li, 2015). The survey concluded that "[b]eing unaware of the IR deposit process stood out as the greatest barrier that accounts for the low participation rate in TAMU" (Yang \& $\mathrm{Li}, 2015)$. It stands to reason that libraries opting to house OER resources in their IR will have work to do in terms of promotion and campus awareness, both for the OER themselves and the repository in which they are housed.

\section{Funding}

For a faculty member, identifying and customizing OER content to replace a traditional textbook can be a time-consuming process. As such, many libraries are offering financial incentives or grant programs to encourage faculty to build and use OER in their classes. For example, Bolick says that in January $2016 \mathrm{KU}$ offered a pilot grant of $\$ 1,500$ to a faculty member who is creating an open textbook for Haitian Creole language instruction (J. Bolick, personal communication, 
October 10, 2016). This past fall, the KU Libraries established a $\$ 50,000$ grant initiative using funds from the KU Libraries Parents' Campaign, an annual giving opportunity for parents of KU students to support the KU Libraries. This money is to be spent over two years, $\$ 25,000$ each year. Grant awards vary in dollar amount; grant recipients could receive up to $\$ 1,000$ for adopting an existing OER and up to \$5,000 for creating an OER where none currently exists (University of Kansas Libraries, n.d.).

The University of Minnesota Libraries' funding program for the creation of OER, called the Partnership for Affordable Content, awards grants between $\$ 500$ and $\$ 1,500$ to faculty and instructors interested in using OER or other alternative materials for a course (University of Minnesota Libraries, n.d.).

Finding faculty willing to create and share OER has been a challenge. That is why we created the incentive grant. A big benefit has been working with willing faculty to create this content and then giving it away to students (and others worldwide) for free. As word of mouth spreads and as more and more faculty see the types of things we have already created I think the program will only grow. (S. Nackerud, personal communication, October 6, 2016)

One of the challenges of these grant incentive programs is long-term sustainability. While some libraries are earmarking portions of their budgets toward the production and promotion of OER, many OER initiatives have been funded through grants or other one-time monies. 
"[I]ncreasingly, institutions are identifying ways to make these efforts sustainable, for example, by advocating for targeted programming money allocated from state government for the purpose of making higher education more affordable" (Chadwell \& Fisher, 2016). As university budgets tighten, securing recurring, sustainable funding for OER will be an ongoing priority.

As part of its effort to establish a Digital Humanities program, the University of North Carolina Greensboro (UNCG) Libraries have developed an interesting alternative to financial incentives. In a presentation at the Charleston Conference in November 2016, Tim Bucknall, assistant dean of University Libraries and head of electronic resources and information technologies, outlined the Digital Partners grant program, through which the UNCG Libraries offer dedicated staff time and library resources, rather than cash awards, to assist in the production of open access content. Recipients of the award receive up to $\$ 22,500$ worth of resources, which could include use of the library's existing hardware and software, as well as staff time. In addition, the UNCG Libraries commit to maintaining the resulting scholarly product and making it available long term (University of North Carolina Greensboro Libraries, n.d.). Examples of current projects in progress for the 2016-2017 academic year include a born-digital version of The Complete Works of George Herbert and an online visual identification guide to the oaks of the Southeastern United States.

The model being implemented at UNCG helps to emphasize that, in addition to the funds and resources allotted to the promotion and creation of OER, academic institutions must consider the staffing dedicated to the support of the OER content as well as the maintenance of the repository. 
At the GVSU Libraries, the Scholarly Communications team, comprised of three full-time people, handles the OER program. The scholarly communications outreach coordinator handles most of the outreach, conducts educational programming, and coordinates the OER group on campus, while the scholarly communications associate uploads most of the content. The library publishing manager works directly with the OER authors.

When we started to see rapid growth in library publishing a few years ago (we publish journals as well as OER) we were fortunate to be able to rewrite an existing position in the Libraries to become our Library Publishing Manager position, which has helped our team immensely in supporting this growth. (S. Beaubien, personal communication, October 10, 2016)

The OER initiative at the KU Libraries is anchored in the Shulenberger Office of Scholarly Communication \& Copyright, while the Digital Initiatives and Discovery unit handles the administration of the repository and the loading of OER into it. "KUSW has been actively supported for a long time now, so the addition of OER to it has no impact yet on staffing levels, as we're able to add these projects into our regular workflows with the regular staff who support them," explains Bolick. OER is only part of Bolick's responsibilities, though, and that limits how much of his time he is able to devote to it. "At some point it may become necessary to hire someone whose primary responsibility is OER,” Bolick acknowledges (J. Bolick, personal communication, October 10, 2016). 


\section{Licensing/Creative Commons}

As mentioned earlier, in addition to the financial benefits for students, a significant advantage of OER for instructors is the ability to pick and choose the pieces of each resource they want to use. When OER are used as the course materials for a class, faculty members need not restrict themselves to a single textbook; they could potentially select the elements of several OER to build a resource tailored to their course needs. The modular nature that enables instructors to pick and choose components to build a customized OER entails the use of a license that is inherently more flexible than traditional copyright. In one sense, OER content can actually be viewed as a response to the restrictions of U.S. Copyright law and the desire for the flexibility to remix and reuse original works (Walz, 2015).

When discussing the copyright and licensing of OER, it is important to acknowledge and understand the differences between open access content and openly licensed content. While open access content is freely available for access by anyone, potential reuse and adaptation of the content is restricted or limited. Openly licensed content, however, is freely available for access, and reuse, adaptation, and remixing of the content is permitted. The most commonly used licenses for OER are Creative Commons (CC) licenses. All CC licenses enable the original creator (licensor in CC terms) to retain copyright while allowing others to copy, distribute, and make some noncommercial use of the original work. CC licenses also require that credit for the content be attributed to the original creator (Creative Commons, n.d.). 
Most of the libraries interviewed for this column mandate the use of a CC license or something similar for the OER they produce. For example, the Partnership for Affordable Content grant at the UMN Libraries stipulates that recipients will license any newly created materials with a Creative Commons Attribution (CC-BY) license or a similar open license (University of Minnesota Libraries, n.d.). Similarly, one of the conditions of the grant initiative at the KU Libraries is that resulting products will be deposited into KUSW with an open license (J. Bolick, personal communication, October 10, 2016).

MIT OpenCourseWare, a web-based publication of virtually all course content from the Massachusetts Institute of Technology, uses the Creative Commons Attribution-NonCommercial-ShareAlike license, abbreviated as CC BY-NC-SA 4.0 (https://creativecommons.org/licenses/by-nc-sa/4.0/). This particular license permits a user to share and adapt the content of the original work for noncommercial purposes, as long as attribution is given to the original work and the adapted content is distributed under the same license.

While many OER use Creative Commons licenses, this is not true for all of them, and even within Creative Commons there are a variety of rights that can be reserved or given away. Some repositories make licensing information very clear, but many do not. (Hess et al., 2016) 
Libraries interested in producing OER content and making it available via an institutional repository will most likely need to assist faculty in selecting appropriate licensing terms for the content they produce. In addition, a mechanism for storing all of the licensing and copyright information for future reference may be useful. For example, in Cleveland State University's repository, EngagedScholarship@CSU, copies of all permission and copyrights associated with the OER are stored in the IR in a dark archive (Goodsett et al., 2016). While not visible on the public side of the site, licensing and copyright information in a dark archive are available for reference by the IR administrator.

\section{Conclusion}

In the "Scholarly Communication" column in the April 2015 issue of College and Research Libraries News, Kristi Jensen and Quill West address open educational resources, arguing that libraries could play a role in transforming teaching and learning through the adoption and promotion of OER. In that piece West asserts, "There is a clear need for institutional level leadership in the adoption of OER as a strategy for improving access and achievement at our institutions. Librarians can fill this role, and in some cases already have." Libraries are already addressing institutional needs by providing funding for OER content, staffing, and expertise in areas such as copyright and licensing. For the academic library to continue take part in the conversation surrounding educational materials and resources used in the classroom, it must adapt to the needs of its faculty, staff, and students. By playing an active role in the creation and storage of OER content, the academic library continues to be relevant to its patrons and the overall university community. 


\section{References}

Chadwell, F. A., \& Fisher, D. M. (2016). Creating open textbooks: A unique partnership between Oregon State University Libraries and Press and Open Oregon State. Open Praxis, 8(2), 123-130.

Creative Commons. (n.d.). Licensing consideration. Retrieved from https://creativecommons.org/share-yourwork/licensing-considerations/.

Goodsett, M., Loomis, B., \& Miles, M. (2016). Leading campus OER initiatives through library-faculty collaboration. College \& Undergraduate Libraries, 23(3), 335-342.

Hess, J., Nann, A. J., \& Riddle, K. E. (2016). Navigating OER: The library's role in bringing OER to campus. The Serials Librarian, 70(1-4), 128-134.

Jensen, K., \& West, Q. (2015). Open educational resources and the higher education environment: A leadership opportunity for libraries. College \& Research Libraries News, 76(4), $215-218$.

Mitchell, C., \& Chu, M. (2014). Open education resources: The new paradigm in academic libraries.Journal of Library Innovation, 5(1), 13-29. 
University of Kansas Libraries. (n.d.). KU Libraries' OER grant initiative. Retrieved from https://openaccess.ku.edu/grant.

University of Minnesota Libraries. (n.d.). Call for proposals: Partnership for affordable content. Retrieved from https://www.lib.umn.edu/elearning/partnership/callforproposals.

University of North Carolina Greensboro Libraries. (n.d.). Digital partners. Retrieved from https://library. uncg.edu/research/support/digital_partners.aspx.

Walz, A. R. (2015). Open and editable: Exploring library engagement in open educational resource adoption, adaption and authoring. Virginia Libraries, 61, 23-31.

Yang, Z. Y., \& Li, Y. (2015). University faculty awareness and attitudes towards open access publishing and the institutional repository: A case study. Journal of Librarianship and Scholarly Communication, 3(1), 1-29. 